Gazi University
Journal of Science
http://dergipark.gov.tr/gujs

\title{
Effect of Ta Content on Microstructure and Phase Transformation Temperatures of $\mathrm{Ti}_{75.5}-\mathrm{Nb}_{25.5}$ (\%at.) Alloy
}

\author{
Safar Saeed MOHAMMED ${ }^{1}$ (D), Fethi DAGDELEN ${ }^{2}$ iD, Ibrahim Nazem QADER ${ }^{1, *}$ \\ ${ }^{I}$ Department of Physics, College of Science, University of Raparin, Sulaymaneyah, Iraq \\ ${ }^{2}$ Department of Physics, Faculty of Science, Firat University, Elazig, Turkey \\ Highlights \\ - The austenite phase transformation decreases with increasing Ta into TiNbTa alloy. \\ - The crystallite size diminishes with increasing the fraction of Ta into the Ti-Nb SMA. \\ - $\beta$ and $\alpha$ " phases were obtained in all Ti-Nb alloy samples.
}

\section{Article Info}

Received: 11 June 2021

Accepted: 15 Oct 2021

\section{Keywords}

Shape memory alloy

$\beta$-titanium alloy

Ti-Nb-Ta

microstructure

\begin{abstract}
$\beta$-titanium shape memory alloys are used as shape memory-based biomedical applications and superelastic materials because they are made up of non-toxic components. Also, their behaviors are more semilar with that of human bone and dental biological tissues, such as biocompatibility, superior corrosion resistance, low density, and low modulus of elasticity. In the current study, the effect of Ta additive on the physical properties of Ti-Nb alloy has been investigated. Ti-Nb-Ta alloy samples were produced such that the Tantalum (Ta) element was substituted instead of Niobium ( $\mathrm{Nb}$ ), and the induction arc melting was used to melting the mixed powders. To investigate the crystal structure, microstructure, and phase transformation temperatures of all samples, the X-Ray Diffraction (XRD), Scanning Electron Microscopic (SEM), and Diffraction Scanning Calorimetry (DSC) measurements have been used. Both $\beta$ rich and $\alpha$ peaks were observed in the XRD and SEM measurements. Also, the DSC results revealed that the $\mathrm{Ti}-\mathrm{Nb}$-Ta alloys have only austenite transformation temperatures and their phase austenite phase transformation were decreased by the effect of Ta additive, additionally, the enthalpy change in $\mathrm{E}_{3}$ sample $\left(\mathrm{Ti}_{75.5} \mathrm{Nb}_{22.5} \mathrm{Ta}_{2}\right.$ (\%at)) has the highest value, while $\mathrm{E}_{4}$ sample $\left(\mathrm{Ti}_{75.5} \mathrm{Nb}_{21.5} \mathrm{Ta}_{3}(\%\right.$ at) $)$ has the lowest respective value.
\end{abstract}

\section{INTRODUCTION}

Shape Memory Alloys (SMAs), which are a subset of smart materials [1] are widely used in engineering technology because, based on two unique characteristics, superelasticity (SE) and shape memory effect (SME), they can restore their original condition after being distorted by applied stress $[2,3]$. Depends on this superior ability they have more applications in variety fields such as robotic [4], aerospace [5], civil structure [6], automotive [7], and aircraft [8]. In addition SMAs have widely used in medical applications because they have high biocompatibility $[9,10]$. Biocompatibility is the ability of an implant to act on living tissue without adversely affecting local or systemic reactions. Tantalum (Ta) and Niobium $(\mathrm{Nb})$ are the biocompatible materials which have more medical applications as nanoparticle or used in alloys [11-13]. Also, Titanium (Ti) is one of the biomedical elements which known to has no opposing biological effects $[14,15]$. Many materials cannot be used as an implant in the human body and some related medical applications such as orthodontic and planting since they are not able to adapt themselves with the living tissues and human bones. Mechanical properties, such as modulus of elasticity are one of those biocompatible properties that should be adopted with the human living tissues and bones, moreover, some other characteristics such as density, corrosion resistance, and biocompatibility should be well investigated in terms of their side effects and relevant disease [16]. Some types of shape memory alloys (SMAs), have a good ability to adapt with human tissues because they have some interesting behaviors which have a 
significant role in medical application [1, 17, 18]. Among all types of SMAs, Ti-based alloys are more attracted to attention in the biomedical field because their behaviors are more similar to that of human bone and dental biological materials [4]. Ti-based SMAs have superior biocompatibility, great corrosion resistance, low density, and low modulus of elasticity $[3,13,19]$. Also, they are used as biomedical shape memory and pseudoelastic materials because it contains non-toxic elements. The shape memory effect (SME) and pseudoelasticity of Ti-based SMAs depend on the reversible phase transformation between $\beta$ and $\alpha^{\prime \prime}$ martensite phase [20]. In some biomedical applications, Ti-Ni alloy is not suitable to use because Nickel is a toxic element and is known to be an allergen in the human body [21]. Therefore, Ti-Nb alloy can be one of the best candidates instead of Ti-Ni alloy because of their non-toxic elements. Also, binary $\mathrm{Ti}-\mathrm{Nb}$ alloy has good mechanical properties, shape memory effect, superelasticity, as well as good biocompatibility at room temperature [22]. Besides, mechanical properties of $\mathrm{Ti}-\mathrm{Nb}$ alloy can be further improved by adding the third elements into it. Ramarolahy et al. added N, O, and Si to Ti-Nb and they found that after adding 0.5 at $\%$ of N, O, and $\mathrm{Si}$, the TiNb-based SMA showed good superelastic properties and low Young's moduli that make them good candidates for biomedical applications [22]. Al-Zain, et al. showed that by adding Mo the maximum recovery and transformation strains of a Ti-Nb alloy increased [23]. Also, there are more other works in the literature that were improved the mechanical properties of T$\mathrm{Nb}$ alloy [24-27].

In the current study, the effect of Tantalum $(\mathrm{Ta})$ on the physical properties of Ti-Nb SMA has been examined. The specimens were prepared by the arc melting technique. Then by using DSC, XRD, and SEM-EDX the thermal characteristics, crystal structure analysis, and microstructure were characterized, respectively.

\section{EXPERIMENTAL PROCEDURE}

A ternary Ti-Nb-Ta was made precisely by means of high pure powder elements, including $\mathrm{Ti}(99.9 \%$ purity), $\mathrm{Nb}$ (99.9\% purity), and Ta (99.9\% purity) with different compositions as indicated in Table 1 . The composition of $\mathrm{Ti}$ stayed constant and the $\mathrm{Nb}$ element was substituted with Ta. After weighted the pure powder elements by a digital balance which has high sensitivity (SCALTEC Analytical balance SBC 31 . $220 \mathrm{~g}$. Readability $0.1 \mathrm{mg}$ ) they were thoroughly combined and pelletized by a mechanical hydraulic compressor (SPACAC) under a pressure of $15 \mathrm{MPa}$. The pellets were melted by using an arc melter device in an argon atmosphere, and then the ingots were chilled inside the chamber to room temperature. Also, for more homogenization, the produced samples were annealed by kept at $850{ }^{\circ} \mathrm{C}$ for 24 hours and then they were quenched in salty-ice water, and finally, all of the samples were cut into small pieces for easy testing.

The influence of Ta on the phase transformation behavior of Ti-Nb alloy was explored using PerkinElmer sapphire differential scanning calorimetry (DSC) in an argon environment at a heating-cooling rate of 10 $\mathrm{K} / \mathrm{min}$. Also, by using X-Ray diffraction (XRD), the crystal structure of all samples was examined at room temperature, by the aid of $K \alpha$ radiation, between $\left(30^{\circ}-80^{\circ}\right)$. Additionally, to detect the surface morphology and microstructural of all samples, a scanning electron microscope (SEM) was employed at room temperature and an energy dispersive scanning x-ray (EDX) was employed to measure the composition of the elements in all alloys.

Table 1. The ratio of the components in their constitution

\begin{tabular}{|c|c|c|c|c|c|c|}
\hline \multirow{2}{*}{ Samples } & \multicolumn{3}{|c|}{ Element composition (at. \%) } & \multicolumn{3}{|c|}{ Element composition (wt. \%) } \\
\hline & $\mathrm{Ti}$ & $\mathrm{Nb}$ & $\mathrm{Ta}$ & $\mathrm{Ti}$ & $\mathrm{Nb}$ & $\mathrm{Ta}$ \\
\hline E1 & 75.5 & 24. 5 & 0 & 61 & 39 & 0 \\
\hline E2 & 75.5 & 23.5 & 1.0 & 60 & 37 & 3 \\
\hline E3 & 75.5 & 22.5 & 2. 0 & 60 & 34 & 6 \\
\hline E4 & 75.5 & 21.5 & 3. 0 & 59 & 32 & 9 \\
\hline E5 & 75.5 & 20.5 & 4.0 & 58 & 31 & 12 \\
\hline
\end{tabular}




\section{RESULTS AND DISCUSSION}

\subsection{Crystal Structure Analysis}

The XRD patterns of all samples are presented in Figure 1, which is carried out at room temperature. All peaks for each sample were indexed by using the literature [28-31]. As shown in Figure 1, both ( $\beta)$ and $\left(\alpha^{\prime \prime}\right)$ peaks were coexisted in all Ti-Nb alloy samples (with and without Ta). Also, it can be seen that the sample $\mathrm{E}_{1}\left(\mathrm{Ti}_{75.5} \mathrm{Nb}_{24.5} \mathrm{Ta}_{0}(\% \mathrm{at})\right)$ exhibited a strong (110) $\beta$ peak and two other weak peaks include (211) $\beta$ and (111) $\alpha "$. But in $E_{2}$ sample $\left(\mathrm{Ti}_{75.5} \mathrm{Nb}_{23.5} \mathrm{Ta}_{1}\right.$ (\%at)) the intensity of (110) $\beta$ peak was reduced and (111) $\alpha^{\prime \prime}$ peak was damaged and the new peak $\left((022) \alpha^{\prime \prime}\right)$ was produced, also, the same result was reported in the literature $[29,30]$. $E_{3}$ with 2 at.\% Ta has the same XRD pattern as $E_{1}$. Besides, the XRD profile of $E_{4}$ and $E_{5}$ reveals that the Ta additive was caused to decrease the intensity of (211) $\beta$ peak while it caused to increase the intensity of (111) $\alpha^{\prime \prime}$, and in $\mathrm{E}_{4}$, a new peak, (201) $\alpha^{\prime \prime}$ with low intensity was produced. Additionally, it can be seen that the intensity of -phase peaks dropped after adding Ta, but the intensity of Ta "-phase peaks remained constant and adding Ta had no effect on their intensity.

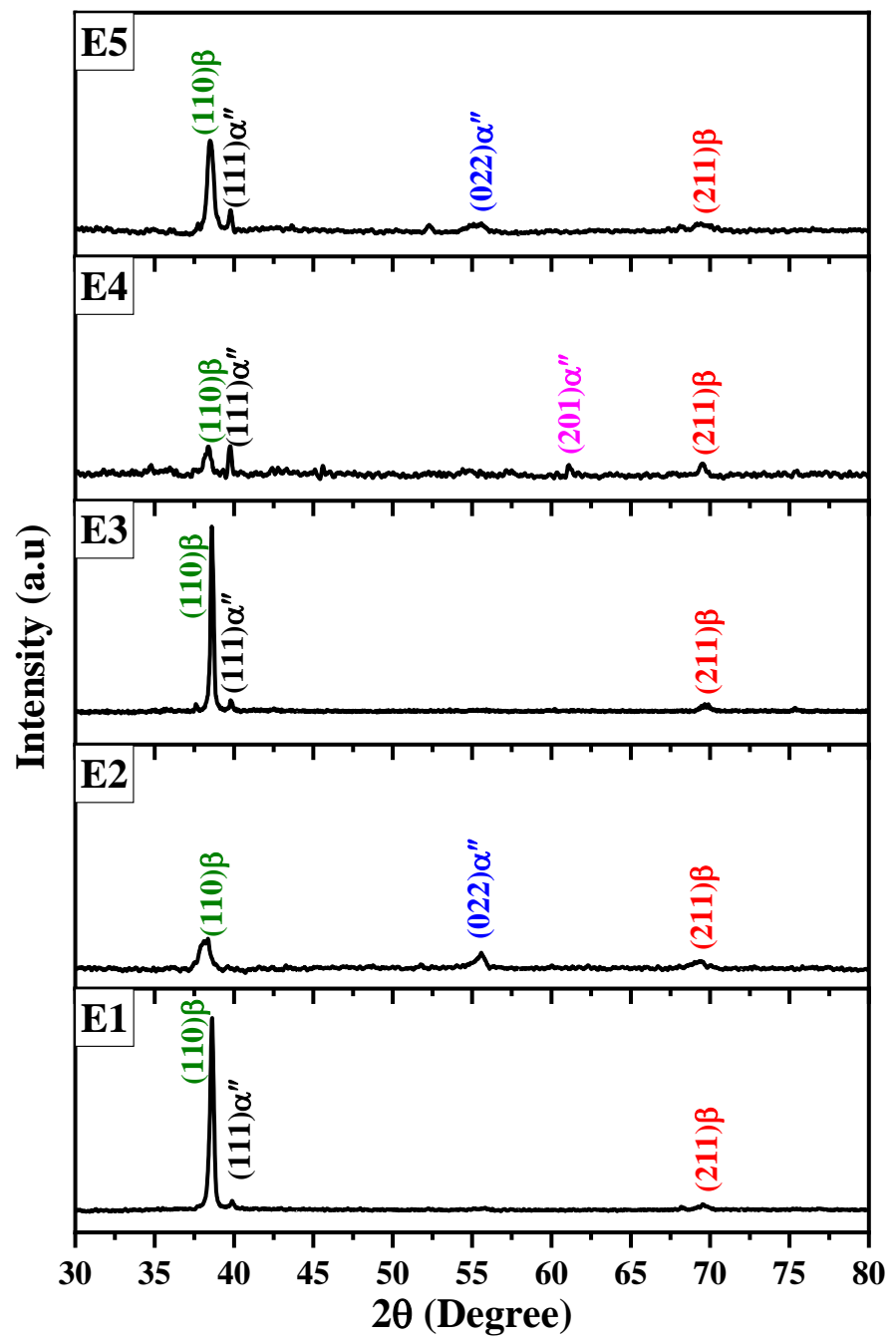

Figure 1. The XRD pattern of Ti-Nb-Ta alloy

The crystalline size of all samples has been calculated by using the Scherrer equation, which depends on the incident $x$-ray $(\lambda)$ with the wavelength of $1.5406 \AA$, the Braggs angle, shape factor $(K=0.9)$, and full width half maximum (FWHM) of the XRD peak that is denoted by $(B)$. The Scherrer is given as follows [32-35]: 


$$
D=\frac{K \lambda}{B \cos \theta}
$$

Figure 2 displays the influence of the Ta additive on the crystallite size of the Ti-Nb alloy. The alloying Ti$\mathrm{Nb}$ SMA with Ta decreased the crystallite size of the alloy.

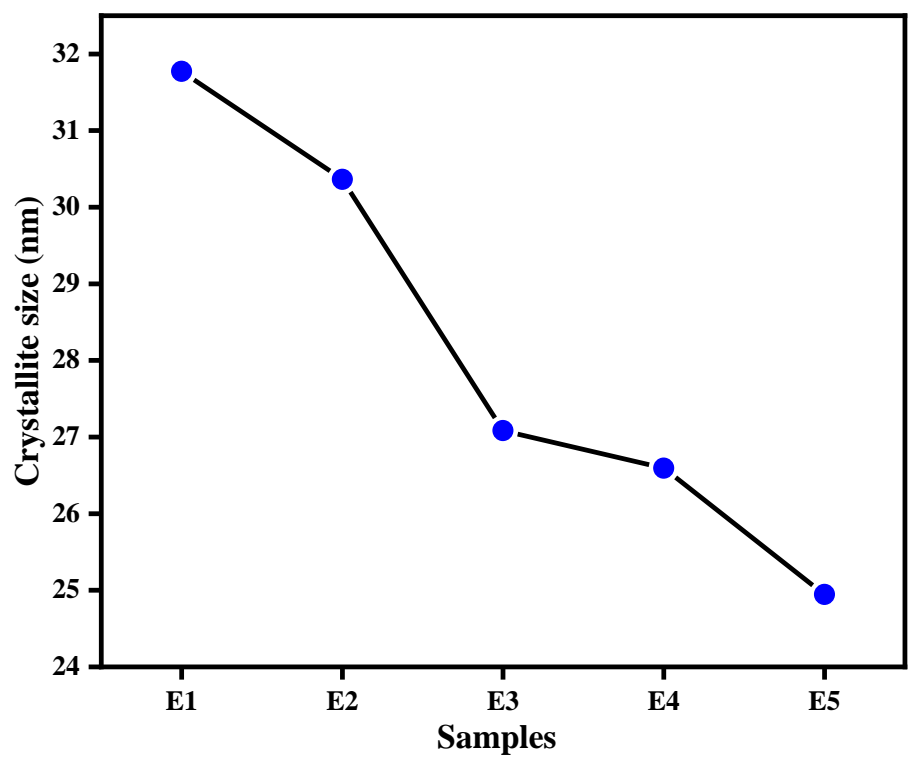

Figure 2. The calculated crystallite size of all samples

\subsection{Microhardness Analysis}

The Vickers microhardness measurement technique was employed at room temperature in this study to explore the effect of $\mathrm{Ta}$ on the microhardness of $\mathrm{Ti}-\mathrm{Nb}$ alloy. There are three types of measurements for each sample; the standard deviation shows that different findings were obtained from different microstructures of each alloy, however, the average value was taken as a typical value (Figure 3). Figure 3 depicts that generally the microhardness was considerably enhanced once Ta was added as the third element to the Ti-Nb alloy.

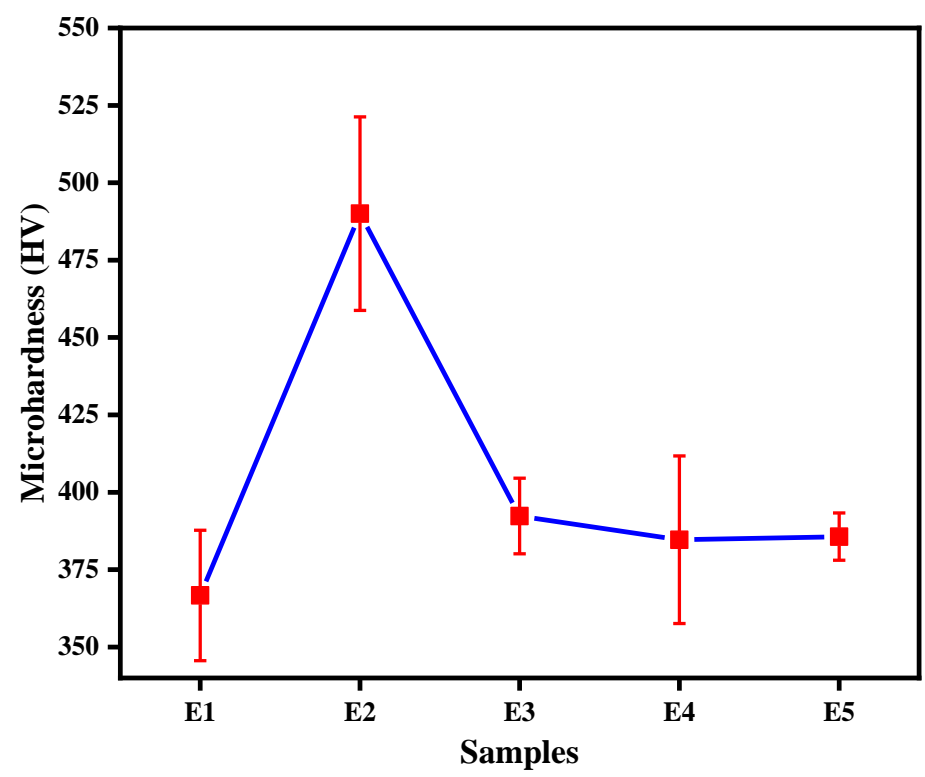

Figure 3. The measured Vickers microhardness of the samples 


\subsection{Microstructure Analysis}

Figure 4 demonstrates the SEM micrograph results of the Ti-Nb-Ta alloys. This measurement was carried out at room temperature. According to Figure 4, the grain boundaries appear in all samples, and adding Ta into Ti-Nb-Ta has no effect on grain boundaries. Also, both $(\beta)$ and $(\alpha)$ phases were detected, where the $\beta$ phase is the matrix, while $\alpha$-phases is the precipitated phase. likewise, Meng et al. [28] reported the same result. As shown in Figure 4, $\alpha$-phases are increased with increasing the amount of Ta, which confirms the XRD result.

\subsection{Phase Transformation Temperatures Analysis}

DSC was employed to determine phase transformation temperatures and other thermodynamic parameters. Figure 5 shows the DSC curves of all samples which are used in the present work. According to DSC results, each sample of the Ti-Nb-Ta SMAs has only the reverse phase transformation temperatures which are $A_{s}, A_{p}$, and $A_{f}$. Also, $\mathrm{E}_{5}\left(\mathrm{Ti}_{75.5} \mathrm{Nb}_{20.5} \mathrm{Ta}_{4}\right.$ (\%at)) has neither forward nor reverse transformation temperatures. The phase transformation temperatures are represented in Table 2 and Figure 6 . According to Table 2 and Figure 6, all of the reverse transformation temperatures $\left(A_{s}, A_{p}\right.$, and $\left.A_{f}\right)$ were decreased by adding Ta into Ti-Nb shape memory alloy. Besides, Figure 7 shows the enthalpy change as a function of changing Ta composition, whereby the enthalpy change, which is the total area under the DSC peaks [36], increased in $\mathrm{E}_{2}\left(\mathrm{Ti}_{75.5} \mathrm{Nb}_{23.5} \mathrm{Ta}_{1}\right.$ (\%at)) and $\mathrm{E}_{3}\left(\mathrm{Ti}_{75.5} \mathrm{Nb}_{22.5} \mathrm{Ta}_{2}\right.$ (\%at)), while its value decreased in $\mathrm{E}_{3}\left(\mathrm{Ti}_{75.5} \mathrm{Nb}_{21.5} \mathrm{Ta}_{3}\right.$ (\%at)).

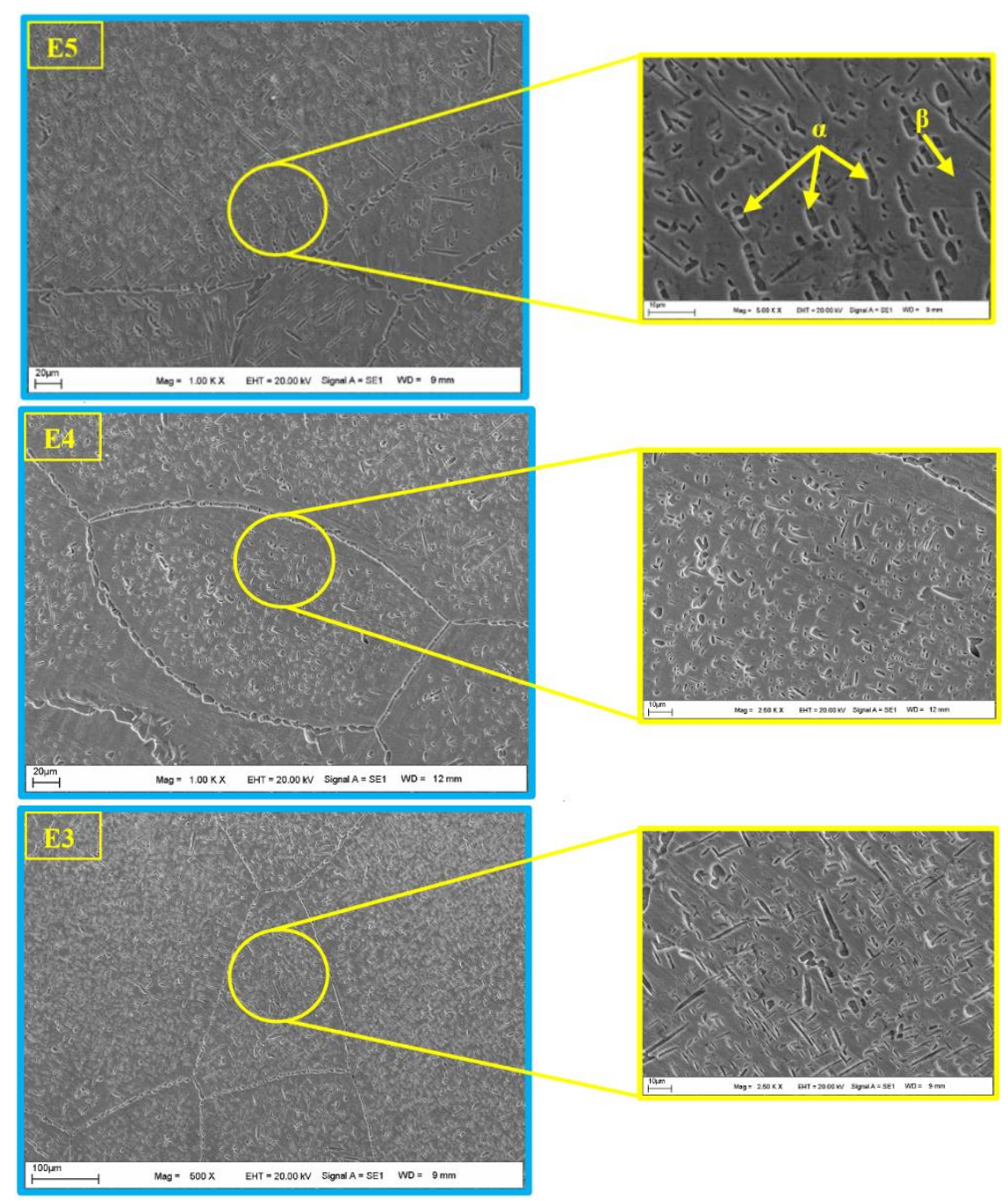




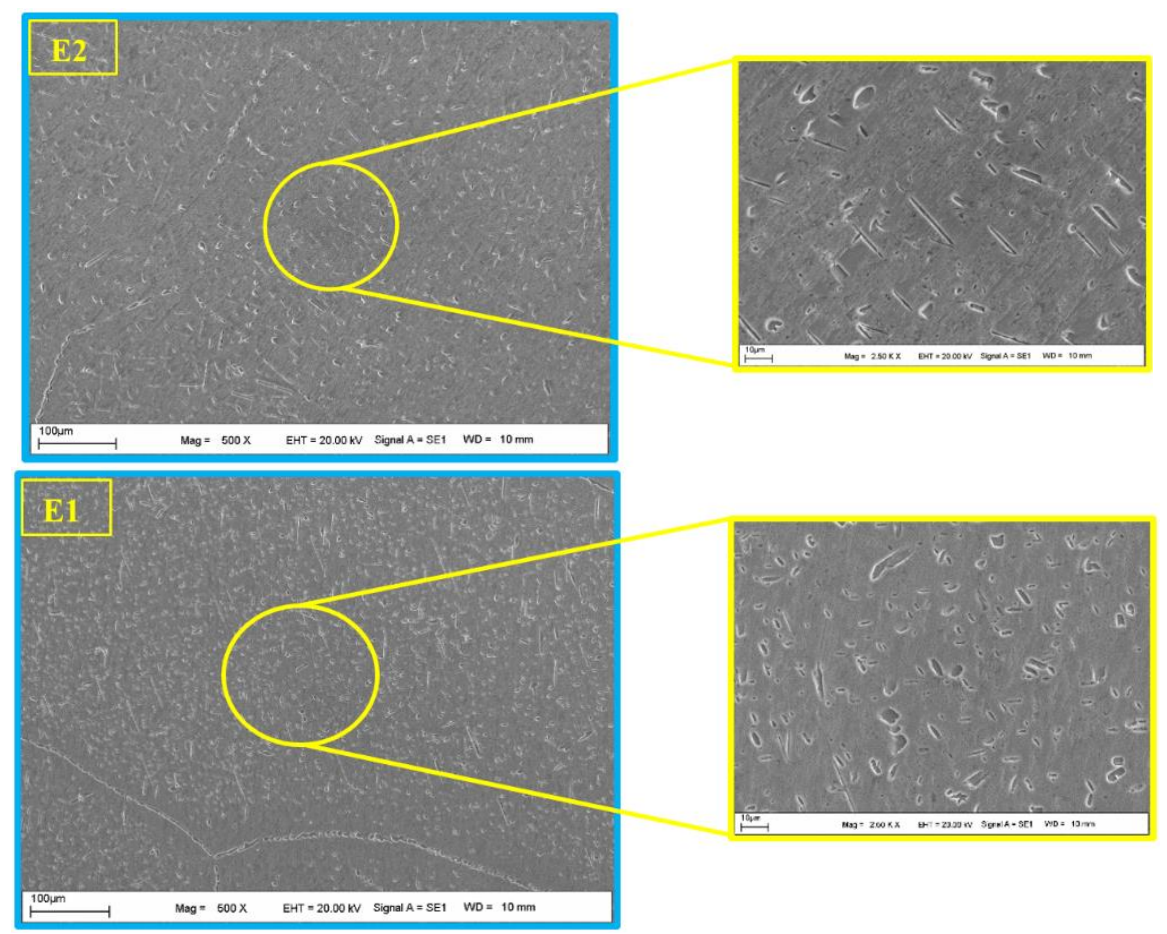

Figure 4. SEM micrographs of the Ti-Nb-Ta SMA

Table 2. Austenite phase transformation temperatures of the alloys

\begin{tabular}{lccc}
\hline \hline Samples & $\begin{array}{c}A_{s} \\
\left({ }^{\circ} \mathrm{C}\right)\end{array}$ & $\begin{array}{c}A_{f} \\
\left({ }^{\circ} \mathrm{C}\right)\end{array}$ & $\begin{array}{c}A_{p} \\
\left({ }^{\circ} \mathrm{C}\right)\end{array}$ \\
\hline \hline $\mathrm{E}_{1}$ & 19.90 & 35.58 & 25.24 \\
$\mathrm{E}_{2}$ & 11.12 & 25.74 & 16.24 \\
$\mathrm{E}_{3}$ & 10.62 & 38.60 & 19 \\
$\mathrm{E}_{4}$ & 11.37 & 29.26 & 16.86 \\
$\mathrm{E}_{5}$ & - & - & - \\
\hline \hline
\end{tabular}

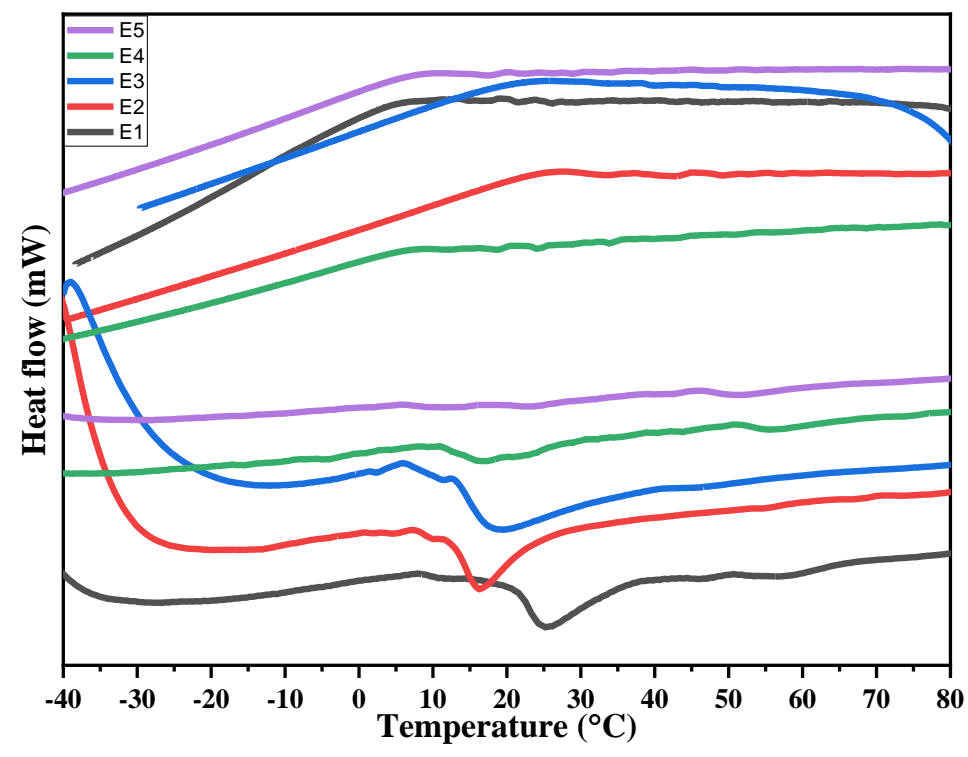

Figure 5. DSC results of Ti-Nb-Ta samples 


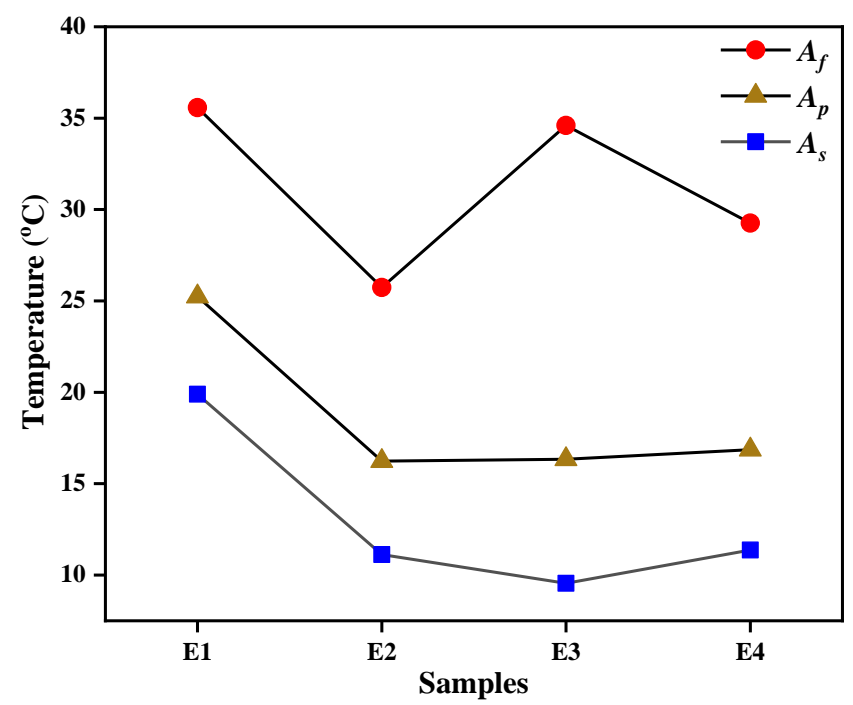

Figure 6. Austenite phase transformation temperatures as a function of Ta composition

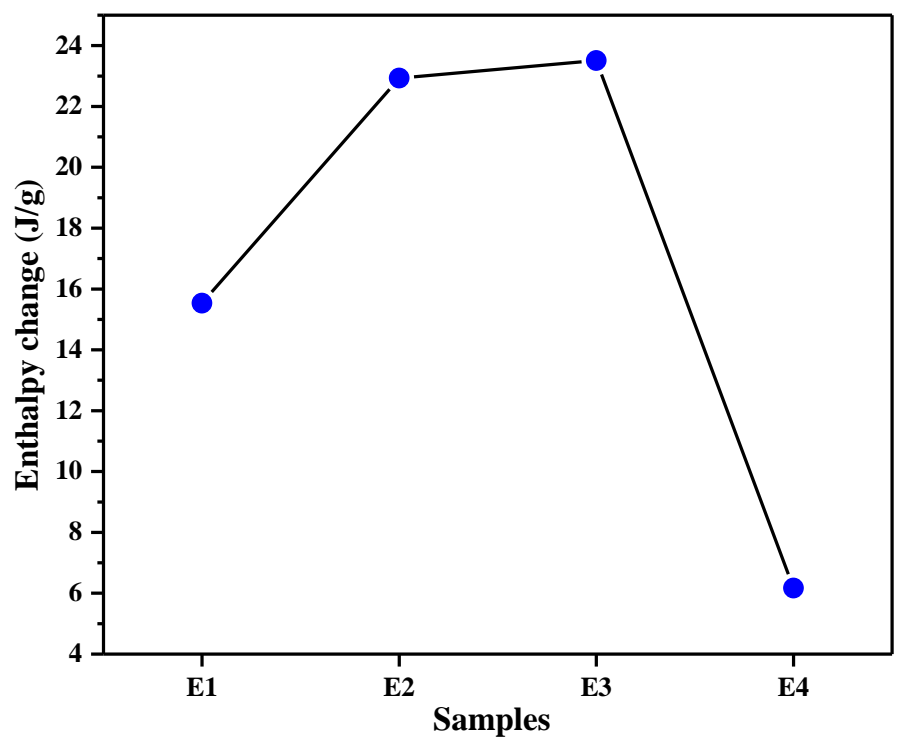

Figure 7. The enthalpy change of the alloy as a function of composition

\section{CONCLUSION}

In this study after $\mathrm{Nb}$ was substituted with low amounts of $\mathrm{Ta}$ in the $\mathrm{Ti}-\mathrm{Nb}$ shape memory alloy. The main obtained results and conclusion is given such that, according to XRD results, both $(\beta)$ and $\left(\alpha^{\prime \prime}\right)$ peaks were indicated in all Ti-Nb alloy samples (with and without $\mathrm{Ta}$ ). Also, Ta decreased the intensity of $\beta$-phase in E2, E4, and E5 alloys, but the intensity of Ta $\alpha$ "-phases did not change after increased the composition of Ta. The crystallite size of the specimens was reduced with increasing Ta into the Ti-Nb SMA. In the SEM results, both $(\beta)$ and $(\alpha)$ phases were observed, which $\beta$-phase represent the matrix, and $\alpha$-phases were the precipitate phase. All samples showed austenite transformation in the DSC measurement, which no martensitic transformation observed. The enthalpy change of E2 and E3 grew as the amount of Ta increased, however it reduced sharply in E4.

\section{CONFLICTS OF INTEREST}

No conflict of interest was declared by the authors. 


\section{REFERENCES}

[1] Qader, I. N., Kök, M., Dağdelen, F., Aydogdu, Y., "A Review of Smart Materials: Researches and Applications", El-Cezerî Journal of Science and Engineering, 6(3): 755-788, (2019).

[2] Dagdelen, F., Aldalawi, M. A. K., Kok, M., Qader, I. N., "Influence of Ni addition and heat treatment on phase transformation temperatures and microstructures of a ternary $\mathrm{CuAlCr}$ alloy", The European Physical Journal Plus, 134(2): 66, (2019).

[3] Kök, M., Qader, I. N., Mohammed, S. S., Öner, E., Dağdelen, F., Aydogdu, Y., "Thermal stability and some thermodynamics analysis of heat treated quaternary CuAlNiTa shape memory alloy", Materials Research Express, 7(1): 015702, (2019).

[4] Mohammed, S. S., Mediha, K., Qader, I. N., Dağdelen, F., "The developments of piezoelectric materials and shape memory alloys in robotic actuator systems", Avrupa Bilim ve Teknoloji Dergisi, (17): 1014-1030, (2019).

[5] Hartl, D. J., Lagoudas, D. C., "Aerospace applications of shape memory alloys", Proceedings of the Institution of Mechanical Engineers, Part G: Journal of Aerospace Engineering, 221(4): 535-552, (2007).

[6] Song, G., Ma, N., Li, H. N., "Applications of shape memory alloys in civil structures", Engineering structures, 28(9): 1266-1274, (2006).

[7] Jani, J. M., Leary, M., Subic, A., editors. "Shape memory alloys in automotive applications. Applied Mechanics and Materials", Trans Tech Publications, (2014).

[8] Barbarino, S., Flores, E. S., Ajaj, R. M., Dayyani, I., Friswell, M. I., "A review on shape memory alloys with applications to morphing aircraft", Smart Materials and Structures, 23(6): 063001, (2014).

[9] Dutta, R., Madangopal, K., Gadiyar, H., Banerjee, S., "Biocompatibility of Ni-Ti shape memory alloy", British Corrosion Journal, 28(3): 217-221, (1993).

[10] Es-Souni, M., Es-Souni, M., Fischer-Brandies, H., "Assessing the biocompatibility of NiTi shape memory alloys used for medical applications", Analytical and Bioanalytical Chemistry, 381(3): 557-567, (2005).

[11] Aslan, N., Ceylan, B., Koç, M. M., Findik, F., "Metallic nanoparticles as X-Ray computed tomography (CT) contrast agents: A review", Journal of Molecular Structure, 1219: 128599, (2020).

[12] Koç, M. M., Aslan, N., Kao, A. P., Barber,, A. H., "Evaluation of X-ray tomography contrast agents: A review of production, protocols, and biological applications", Microscopy Research and Technique, 82(6): 812-848, (2019). 
[13] Dagdelen, F., Balci, E., Qader, I. N., Ozen, E., Kok, M., Kanca, M. S., Abdullah, S. S., Mohammed, S. S., "Influence of the $\mathrm{Nb}$ Content on the Microstructure and Phase Transformation Properties of NiTiNb Shape Memory Alloys", JOM, 72(4): 1664-1672, (2020).

[14] Ilhan, M., Koç, M. M., Coşkun, B., Erkovan, M., Yakuphanoğlu, F., "Cd dopant effect on structural and optoelectronic properties of TiO 2 solar detectors", Journal of Materials Science: Materials in Electronics, 32(2): 2346-2365, (2021).

[15] Kara, F., Kurban, M., Coşkun, B., "Evaluation of electronic transport and optical response of two-dimensional Fe-doped $\mathrm{TiO} 2$ thin films for photodetector applications", Optik, 210: 164605, (2020).

[16] Davis, J. R. Handbook of materials for medical devices. 1st edition, (2003).

[17] Mohammed, S., Kök, M., Çirak, Z., Qader, I., Dağdelen, F., Zardawi, H., "The relationship between cobalt amount and oxidation parameters in NiTiCo shape memory alloys", Physics of Metals and Metallography, 121(14): 1411-1417, (2020).

[18] Qader, I. N., Öner, E., Kok, M., Mohammed, S. S., Dağdelen, F., Kanca, M. S., Aydoğdu Y., "Mechanical and Thermal Behavior of Cu 84-x Al 13 Ni 3 Hf x Shape Memory Alloys", Iranian Journal of Science and Technology, Transactions A: Science, 45(1): 343-349, (2021).

[19] Mohammed, S. S., Kok, M., Qader, I. N., Kanca, M. S., Ercan, E., Dağdelen, F., Aydoğdu, Y., "Influence of Ta Additive into Cu84-xAl13Ni3 (wt\%) Shape Memory Alloy Produced by Induction Melting", Iranian Journal of Science and Technology, Transactions A: Science, 44(4): 1167-1175, (2020).

[20] Kim, H. Y., Sasaki, T., Okutsu, K., Kim, J. I., Inamura, T., Hosoda, H., Miyazaki, S., "Texture and shape memory behavior of Ti-22Nb-6Ta alloy", Acta Materialia, 54(2): 423433, (2006).

[21] Huang, H.H., Chiu, Y.H., Lee, T.H., Wu, S.C., Yang, H.W., Su, K.H., Hsu, C.C., "Ion release from NiTi orthodontic wires in artificial saliva with various acidities", Biomaterials, 24(20): 3585-3592, (2003).

[22] Ramarolahy, A., Castany, P., Gloriant, T., Prima, F., Laheurte, P., Eberhard,t A., Patoor, E., editors. "Synthesis and characterisation of new superelastic and low elastic modulus $\mathrm{Ti}-\mathrm{Nb}$ $\mathrm{X}$ alloys for biomedical application", Advanced Materials Research, Trans Tech Publications, 409, 170-174, (2011).

[23] Al-Zain, Y., Kim, H., Hosoda, H., Nam, T., Miyazaki, S., "Shape memory properties of TiNb-Mo biomedical alloys", Acta Materialia, 58(12): 4212-4223, (2010).

[24] Ping, D., Cui, C., Yin, F., Yamabe-Mitarai, Y., "TEM investigations on martensite in a TiNb-based shape memory alloy", Scripta Materialia, 54(7): 1305-1310, (2006).

[25] Fukui, Y., Inamura, T., Hosoda, H., Wakashima, K., Miyazaki, S., "Mechanical properties of a Ti-Nb-Al shape memory alloy", Materials Transactions, 45(4): 1077-1082, (2004). 
[26] Zhang, J., Sun, F., Hao, Y., Gozdecki, N., Lebrun, E., Vermaut, P., Portier, R., Gloriant, T., Laheurte, P., Prima, F., "Influence of equiatomic Zr/Nb substitution on superelastic behavior of Ti-Nb-Zr alloy", Materials Science and Engineering: A, 563: 78-85, (2013).

[27] Hussein, A. H., Gepreel, M. A.-H., Gouda, M. K., Hefnawy, A. M., Kandil, S. H., "Biocompatibility of new Ti-Nb-Ta base alloys", Materials Science and Engineering: C, 61: 574-578, (2016).

[28] Meng, Q.-K., Huo, Y.-F., Ma, W., Sui, Y.-W., Zhang, J.Y., Guo, S., Zhao, X.Q., "Design and fabrication of a low modulus $\beta$-type $\mathrm{Ti}-\mathrm{Nb}-\mathrm{Zr}$ alloy by controlling martensitic transformation", Rare Metals, 37(9): 789-794, (2018).

[29] Wang, B., Zheng, Y., Zhao, L., "Effects of Sn content on the microstructure, phase constitution and shape memory effect of $\mathrm{Ti}-\mathrm{Nb}-\mathrm{Sn}$ alloys", Materials Science and Engineering: A, 486(1-2): 146-151, (2008).

[30] Kim, H., Hashimoto, S., Kim, J., Inamura, T., Hosoda, H., Miyazaki, S., "Effect of Ta addition on shape memory behavior of Ti-22Nb alloy", Materials Science and Engineering: A, 417(1-2): 120-128, (2006).

[31] Hao, Y., Li, S., Sun, S., Zheng, C., Yang, R., "Elastic deformation behaviour of Ti-24Nb4Zr-7.9 Sn for biomedical applications", Acta biomaterialia, 3(2): 277-286, (2007).

[32] Tatar, C., Haji, A. I., Qader, I. N., "Heat Treatment Effects on Microstructural and Thermal Properties of High Cu Content NiTiCu Shape Memory Alloy", Iranian Journal of Science and Technology, Transactions A: Science, (2021).

[33] Qader, I. N., Kok, M., Cirak, Z. D., "The effects of substituting Sn for Ni on the thermal and some other characteristics of NiTiSn shape memory alloys", Journal of Thermal Analysis and Calorimetry, 145(2): 279-288, (2021).

[34] Tatar, C., Acar, R., Qader, I. N., "Investigation of thermodynamic and microstructural characteristics of NiTiCu shape memory alloys produced by arc-melting method", The European Physical Journal Plus, 135(3): 311, (2020).

[35] Kök, M., Aydoğdu, K., Kanca, M. S., Qader, I. N., Öner, E., Coşkun, M., "Effects of Aging on Magnetic and Thermal Characteristics of NiMnCoSn Magnetic Shape Memory Alloys", Iranian Journal of Science and Technology, Transactions A: Science, (2021).

[36] Balci, E., Dagdelen, F., Qader, I. N., Kok, M., "Effects of substituting Nb with V on thermal analysis and biocompatibility assessment of quaternary NiTiNbV SMA", The European Physical Journal Plus, 136(2): 145, (2021). 